\title{
Reflections on education policy in Spain: a problematic discipline
}

\author{
Manuel de Puelles Benítez \\ Dpto. Historia de la Educación y Educación Comparada, UNED, Spain \{mpuelles@edu.uned.es\} \\ Received on 18 March 2013 revised on 29 March 2013; accepted on 21 April 2013; published on 15 July 2013 \\ DOI: $10.7821 /$ naer.2.2.48-53
}

\begin{abstract}
Education policy in Spain, a curricular discipline in the Education Faculties since 1974, has been a foreign body -because of its inevitable connection with political sciences- both in the former Degree in Education and in the current one, a result of the curriculum adaptation to the European Higher Education Area (EHEA). The Degree in Education aims to train teachers, not education-oriented political scientists, but, unlike other similar disciplines -education sociology or education economy- which have managed to find their place in the curriculum as supplementary knowledge, education policy runs the risk of being distorted if we do not root it in the political sciences it stems from. The reflections presented in this paper therefore focus on the three major problems the discipline does not get to resolve: its conceptual indeterminacy, the right nature of this body of knowledge and the lack of canonical boundaries of its knowledge fields.
\end{abstract}

KEYWORDS: EDUCATIONAL POLICY, POLITICS OF EDUCATION, POLITICAL SCIENCE

\section{THE CONCEPTUAL INDETERMINACY PROBLEM}

Education policy is born in Spain as a discipline with the curriculum of the Degree in Education in 1974 -almost forty years ago. Even though that is hardly a long period from a historical perspective, from our personal experience such a period can easily represent half a life. It is, therefore, long enough for us to try and analyse the lessons learned during this small period of history. A first appreciation, as a result of its back history, is the existence of multiple names to make reference to it, a plurality that still exists. This conceptual indeterminacy is a sign of the existence of a foundational problem: it lacks a clear conception as a discipline. This would involve clarifying some basic problems for any discipline, such as the specification of its nature and its object.

The discipline has been called "educational politics and legislation", a name that has been kept through the different curricular changes. It has however coexisted with other different names: "education policy" most of the time, "education policy and administration" sometimes, and "education politics" to a lesser extent.

\footnotetext{
"To whom correspondence should be addressed: Universidad Nacional de Educación a Distancia (UNED) $\mathrm{P}^{\circ}$ Senda del Rey, 7 28043 Madrid

Spain
}

We have therefore an official name and some others that have been appearing and receiving acceptance throughout the years, although the three last names stated above prevail. This name diversity comes to show the different aspects that universities have emphasised such as legislation, administration or education policies. The last name mentioned above, "educational politics", is the more abstract but more accurate one, as we will see, similar to those used in other more established disciplines in the current Degree in Education, such as education sociology and education economy.

Twenty years after it first appeared, in 1992, as a consequence of the curricular reform promoted by the 1983 Spanish University Reform Act, the name "educational politics and legislation" would be fixed. Within this small maze of names, there is only one positive thing I can appreciate, which is the political voice of the discipline remaining in all the name variations.

This is highly significant, for it stresses politics is at the core of the discipline and law complements it, becomes instrumental and makes reference to the means. There was at the time, however, an attempt to call the discipline "educational politics". There was a proposal at the Conference for Deans of Educational Sciences Faculties that was taken to the University Council about the name (and object) of the discipline during the 1990s curricular reform. However, the name that got the approval was, as has been previously mentioned, "educational politics and legislation". This official name has been kept through the curriculum reform that took place in the 2000s after the implementation of the European Higher Education Area, even though the name "educational politics" would have come closer to the true nature of the discipline.

Why this emphasis on educational legislation? I believe that this emphasis responds to the weight of tradition. The term school legislation, and its incorporation into the curriculum, was born in the first third of the 20th century in the curriculums of teacher training Normal Schools.

It was then considered that teachers should have some legislation knowledge on primary education: curriculum foundations, teacher's legal obligations, school calendar, teacher's rights, the record books the school must have always ready for an inspection, etc.

As can be appreciated, the discipline was born with a practical intention, in order to facilitate teachers' duties. The truth is it then became established in the Normal Schools' curriculum, also after the 1974 curricular reform, possibly because the authors of the new curriculum thought it would be a good idea for an 
innovative subject on "policy" to be accompanied by a strong link to tradition and to school legislation.

This preventive attitude must have possibly eased the reception of the new discipline, but it weakened it at the same time. It darkened the incorporation of a new discipline, related to political science, which focuses on education and encompasses, therefore, not just legislation but also other subjects that complete the student's education.

This conceptual reflection is reinforced if we examine the role that politics and education legislation played in the curriculum. The fact that the discipline was born in the 1970s as an elective subject is neither accidental nor irrelevant. It is a fact that I find to be relevant.

It is as if the authors of the curriculum were not very sure about this innovative approach and proceeded to go ahead with a discipline that would occupy a shy and humble space, and would not bother anybody (we are all aware of the discipline conflict that always comes with the adoption of new curriculums).

This cautious attitude was possibly quite wise because twenty years later, the 1992 curricular reform turned it into a core subject, placing it in a leading place among the other traditional disciplines of the Degree in Education.

Finally, the last reform, which has turned the former licenciatura degrees into grados, according to the Bologna philosophy, has confirmed the discipline as a core subject, although under the aforementioned name "educational politics and legislation".

This little return to Ithaca, to the origins, and the journey itself, highlights two aspects that rest on education policy from the start: firstly, that if we consider its appearance from the perspective of the history of academic disciplines, it is a quasiadolescent subject and is therefore far from the academic maturity that everyone interested in the discipline would hope for; in other words, that historically we are rather still in the implementation stage and not in a consolidation stage in the field of university knowledge.

Secondly, despite all legal and real changes, the term "politics" has been kept as the essence of the discipline. However, if we want its consolidation in the near future, we have to approach the discipline from the field of the political sciences, mother of all policies, which implies rooting education policy in the scientific methodology, the categorical apparatus and the paradigms of political science. Education policy needs them to address the problems that are still unclear, especially those about its nature and its knowledge fields.

\section{THE NATURE OF EDUCATION POLICY PROBLEM}

Social sciences have found many obstacles along the way when it has come to become a consolidated subject in academia. Some have been external obstacles, due to the complexity of the objects of study, which are related to something as dynamic and complex as modern societies, but others are internal obstacles, born from the act of knowledge itself. The later ones were called epistemological obstacles by Bachelard. Education policy has not yet overcome these obstacles.

The first epistemological obstacle is the polysemy of the political voice, the existence of, at least, two different meanings depending on the level we place ourselves at: policies as an activity and politics as an area of knowledge of a certain reality. Thus we have, on the one hand, education policy as an activity - the public policies on education- and, on the other, educational politics as the global knowledge on education understood as a political phenomenon, i.e. the political dimension of education, which includes the analysis of the specific policies within this framework.

I understand, therefore, that educational politics (politica de la educación) studies education as a political phenomenon, while education policy (politica educativa) studies the specific policies carried out in a specific time or place. Therefore, with the Spanish voice, "política", we are making reference not just to one specific activity, but also to the relations arising from this activity, which are troublesome by nature because, as pointed out by Weber long ago, they are relations of domination. In English, the voice policy is used when discussing the educational policies and politics to discuss the potentially conflicting phenomenon of educational politics.

In English policy makes reference to the plan of action, while politics refers to the conflict that results from the confrontation of interests and values that underlie the area of education; that is to say, politics analyzes the conflicts that take place in the public sphere of education.

Educational politics has held in Spain, and in general in the countries of our cultural context, a relatively poor treatment. Until recently policy has prevailed, the policy applied to education, political action programs, most of the time without making reference to the ideas of power and struggle around them, stressing the program-oriented aspect and hiding the struggle and conflict.

It is not, as we all know, a subtle nuance, because behind it there are groups advocating for a particular policy, or strongly opposed to a specific policy, or interests and ideologies protected by education policies, or the global political orientation that prevails in education systems, etc.

As has already been pointed out, paying attention to education does not mean giving up the study of educational, instrumental and medial politics - policy- but, assuming this, it also tries to get to know this other aspect of reality which is the conflict in education, education relationships with power, the relationship between the end and the means or, in other words, politics.

As in politics there is always a plurality of ends, there is invariably an underlying conflict because behind every choice of and end there are interests and, ultimately, values, which are everywhere to be found in politics. However, if there are values at play, will educational politics be a normative discipline, prescriptive, which assumes this? Or, on the contrary, will it be an empirical and positive discipline that avoids them?

We thus come to one of the big problems of politics, not yet resolved, linked to political science since it originated. For almost 2500 years there has been a duality that can be appreciated in the initial opposition that Plato's and Aristotle's thought represented.

For Plato, politics is a guide for action, and the virtue of politics is knowledge: that is why the king philosopher, which has the political virtue because he has reached knowledge, must be the one that rules as he is the most well-prepared one. As he has the virtue of politics he knows what to do, what must be done. Plato reflects this in the famous passage of The Republic: "there is no end to suffering, Glaucon, for our cities (...) unless either philosophers become kings in our cities". (Plato, 2005, p. 175).

Instead, Aristotle, from a very critical position towards platonic idealism believes that politics only describes and 
analyses political phenomena the way they are, not the way they should be. It is significant, however, that the subject matter of politics is included by Aristotle in his Nicomachean Ethics, where he writes towards the end:

...on the basis of our collected constitutions, trying to observe what sorts of things preserve and destroy cities, and what sorts have these effects on each type of constitutions, and what the causes are whereby some cities are finely governed and others the opposite. (Aristotle, 2002, p. 258).

This study will be made in his work Politics, using the analysis of the political regimes in the Greek polis. It is sometimes forgotten, though, that it is precisely in this work where Aristotle tries to find the best possible regime, although upon the examination of the existing ones, hence establishing a bridge between the world that must be and there world there is, between the world of values and reality.

However, what is going to take place in Western thought is the abrupt separation between political philosophy, on the one hand, and what will later be called political science, on the other, although the former will prevail for centuries over all other empirical considerations of politics. As noted by a prestigious political scientist of our days, there is a clear difference between "the political science related to the empirical field of 'politics', and political theory, which is related to philosophy, which do not ask themselves about the facts of politics, what about the essence of what politics are" (Mouffe, 2007, p. 15).

In the Renaissance it was Machiavelli who drew the attention towards the need to observe reality directly and avoid philosophical speculation. The observations he makes in chapter $\mathrm{XV}$ of The Prince come to mind, when he states his intention is to write something useful for politicians, so he will focus on the reality of things and not the ravings of the imagination because "many have imagined for themselves republics and principalities that no one has ever seen or known to be in reality. Because how one ought to live is so far removed from how one lives" (Machiavelli, 1997, p. 57). He concludes saying that if order to govern men we abandon the study of what they actually do and study what they should do instead, the politician that has taken that path will head towards his ruin and self-destruction. This dilemma, which focuses on these two different dimensions, will appear, as we will see, in the relationship between politics and education.

A few years later Bodin, when he wrote his Les six livres de la République focusing on something that will be revolutionary for politics for several centuries, the invention of sovereignity, will insist on the same path to the knowledge of political reality as Machiavelli: observing things the way they are, not the way we wish they were. In this work, Bodin says explicitly that he does not want to "design an ideal republic, unachievable, in the style of the ones imagines by Plato and Thomas More, Lord Chancellor of England, but to stick to political rules as much as possible." (Bodin, 1985, p. 12).

The analysis by Machiavelli and Bodin stress the not philosophical, non-speculative, and positive as will be said later, of political studies. The culmination of this trend can be found in Mostesquieu who, in his classical work, De l'esprit des lois, highlights the objective and descriptive sense of political phenomena. This basic principle appears unmistakably in the preface that Montesquieu wrote for his work.

There he states: "I have examined men first and I thought that, amid the infinite diversity of laws and habits, they do not act just according to fantasy but are also governed by laws"
(Montesquieu, 1985, p. 229). As law is a key part of his thought, when the reader is done with the preface and starts reading the first chapter of the first book, the first thing that is found is the concept of those laws that govern men: "Laws, in their broadest sense, are the necessary relations arising from the nature of things" (Montesquieu, 1985, p. 232). The adjective to describe these relations clearly indicates that laws are not a result of speculation but of need which, at the same time, is a result of the nature of things, a noun that in Western thought clearly alludes to what things are, not what we would like them to be.

Although, as indicated earlier, political thought has oscillated between these two tendencies, and sometimes both have coexisted. The Age of Enlightenment is proof of this. While Montesquieu tried to stick to the facts in his examination of the political reality, Rousseau returned to the old tradition of political philosophy and strived to teach how to reach the best possible political system, thus resorting to the theory and not the acts themselves. The words he used to introduce his Discours sur l'origine et les fondements de l'inegalité parmi les hommes leave no room for doubt: "Let us begin by discarding all the facts, for they are not related at all to the question" (Rousseau, 1971, p. 132).

It has been said, and quite rightly too, that this Rousseaunian conception -the realm of what has to be applied to politics- was the idea that guided the revolutionary French bourgeoisie. However, when we applied this Rousseaunian concept to the revolutionary practice, the experiment failed. The big aspirations of Rousseau's thought clashed heavily with the demands of reality. In Freudian terms, we could say that the big principles could not withstand the most modest proof- the principle of reality.

Perhaps this explains the tragic dilemma that was presented to the Jacobins: to impose despotism of liberty and comissarial dictatorship to save the republic of freedom; to save the republic of equality, impose terror and, what might be even worse, make compulsory republican virtue, a prelude to what would be the fields of political "reeducation" in the $20^{\text {th }}$ century. The experience of French Revolution and of the social crisis that took place there, revealed that political philosophy, as it is embodied in reality, showed all its limitations, making way for a new consideration: positive attitude towards facts. It was the return back to Montesquieu.

Indeed, against Rousseau's thought "I look for reason and law and do not argue the facts", prevailed the return to Montesquieu and his "here we say what it, is and not what it should be". (Duverger, 1981, p. 23). This is when modern political science emerged and political philosophy was wiped out from it.

This is how sociology was born and, within it, political science. This young science becomes positive in contrast to the abstraction that permeated political philosophy. Political science becomes empirical, reduced to the analysis of political facts. A priori concepts, teleological approaches, deductive hypothesis, all of this will be totally excluded and considered to be nonscientific.

It was the triumph of positivism in the 19th and part of the 20th centuries. After this brief overview of the antithesis within the social sciences, the consideration of educational politics as a branch of political science explains why it is defined as an empirical discipline, subject to the reality of political events that surround the world of education, which implies studying power relations in education and the conflict that arises from them. 


\section{THE PROBLEM OF THE KNOWLEDGE FIELD}

The fact of education policy being configured as a young discipline explains that the knowledge fields still do not occupy a fixed and canonical place. Moreover, what can be an unavoidable field for some may seem completely dispensable for others. The idea is obviously not to raise a sterile battle between the delimitation of fields, but no academic discipline can survive without determining, agreeing by consensus, its areas of knowledge. Surely the canonical establishment of the discipline's object will facilitate a better understanding of the nature of education policy.

In my opinion, the fields of knowledge that should be studied would have to stick to what we might call the core nerve of the discipline, the central nerve, or those topics which are bound to remain in the coming decades. These fields, in my opinion, are at least four: values, subsumed in the broadest context of educational ideologies; actors, including a special consideration of collective actors, especially interest groups and political parties, and, above all, the study of the macroactor which is the State; the study of the curriculum, and especially curriculum policy; and a review of the educational policies, neglected today even by the public policy movement itself.

There are certainly other possible fields, especially the analysis of the different levels of government in decentralized education systems, with a special emphasis in the European Union, the supranational sphere than already conditions many of the public policies (as has already happened in university education), but the quarterly conception of subjects, or halfyearly at most, of the new degrees, requires the canonical areas to be covered in that period of time.

\subsection{Values}

We know with Max Weber that values cannot be verified empirically. This explains that until a few decades ago the values in the social sciences were suffering the effects of a nineteenth-century positivism which, as a legacy of the past, must be overcome, because the alleged scientific neutrality overlooks that values exist, both objectively and subjectively.

Nowadays we know that it is not possible to dispense with the values in the social sciences, not only because they exist (which is a fact that cannot be doubted, since both values and facts are part of reality), but also because they are inevitable linked to the scientist carrying our his/her work, similarly to, using Ortega and Gasset's brilliant metaphor, the scudding cloud that cannot get rid of the droplets that it is made of. It is the old problem of science's objectivity and the scientist's subjectivity.

The subjectivity of the social scientist seems to be evident today. Even assuming the most aseptic treatment of political problems, it is obvious there may be a latent valuation, because the social scientist is ultimately influenced by the values of his/her time and of the social groups he/she belongs to: and even more, it may be that from an alleged neutrality the social scientist is actually tacitly supporting the values of the society he/she lives in, or leaning towards some values against others.

Therefore, as Weber himself pointed out, we do not have to look for the social scientist without values, but rather to know from the start the values he starts from, the position in which he/she, in fact, is. Taking an "objective" position and not questioning the morality and the conflict of educational relations in society can help to tacitly support the status quo, which is certainly a clearly political act, although not visible.
The neutrality request often conceals the political dimension of the facts and it deprives the existing interests in an open discussion in the political arena. Because the answers given to the existing problems are not neutral: they are connected to the interest of the different social groups, with the values that protect them and the theories that sustain them, which is to say, they are connected to different ideologies. I think our discipline must try to focus on the empirical analysis of the education policy reality, but not forgetting to study the specific weight of the ideologies.

The study of educational ideologies should be therefore an object of education policy. Although some would like ideologies to disappear from the map of politics, this is not possible because conflicts in a pluralistic democracy, also in education, reflect the values that inevitably compete with each other to assert themselves, which explains that even if the end of ideologies is announced, they always come back.

When conservative values predominate -what we would call the ideological right-, priority issues appear in the political agenda such as school performance, discipline in the classroom, education efficiency, competition between schools, etc. When the values that predominate are from the ideological left, the problems to solve make reference to equity in education and therefore the effectiveness of the right to have an education, equal opportunity in education, early childhood education as a compensatory instrument, the access of all population to secondary education, open door policy for university, restricted only by the principles of merit and publicity, etc.

All this is but a consequence of two different ideologies derived from the old principles of freedom and equality. The first one emphasizes freedom of choice in education by parents and students, and insists in the need to teach Religion, supports free creation of shools, defends private education, etc. The second one stresses equality: free financing public schools, compensatory education, immigration or marginalized citizens' integration programs, school reforms that promote more and better education for all, etc. There is, therefore, a continuum characterized by the permanent tension between freedom and equality. Although there have been some attempts and significant achievements in this task of trying to reconcile multiple tensions, the conflict still remains.

\subsection{The actors}

Interest groups have been recognised in modern societies as collective actors. The literature on these groups is now extensive, but it has focused mostly on the study of economic groups, whether national or transnational. It is an obvious statement to claim that studies on the groups of interest related to education are extremely scarce and incomplete. Studying the nature of these groups, their involvement in the preparation of educational policies, the means they use to defend their interests -negotiating with the government, media and opinion campaigns, street demonstrations, teacher and student strikes, formal or informal consultation of the public authorities, etc. are aspects that require urgent attention from education policy.

Certainly, neither the nature of these groups and the means they use today or the interests they defend -material and ideological- are similar, they are aspects that depend on the type of group involved: student associations, parents' of students associations, teachers associations and unions, education business associations. The Catholic Church issue, as an interest group, certainly deserves a separate chapter within this area. 
In a discipline such as education policy, political parties are important actors. Although it is commonplace to state that the boundary between the political right and the left has faded enough to question the existence of such distinction, here, as in the case of ideologies, reality is often quite obstinate as a result of the persistence the two great principles that illuminated the French Revolution, those of freedom and equality.

They persist because while the former gave way to a powerful ideology -liberalism- advocate of individual freedom and civil rights against the State, the second became the stronghold of a new reformulation of the old Athenian democracy representative democracy- that makes suffrage's equality and political freedom the backbone of public life. It is true that in the early twentieth century both political movements began to converge, leading to liberal democracy, but it is an unstable balance between freedom and equality that cannot avoid conflict.

For example, currently, political right parties in education put the emphasis on freedom of school choice, the spearheaded of conservative neoliberalism in this area. Political left parties, however, focus primarily on the principle of equal rights to education. The policies of the parties, once in power, put the emphasis on one or another principle of freedom or equality, and in a particular interpretation of them, which continues to introduce some instability in educational reform policies. It seems inexcusable for education policy to deal with these issues from the perspective of the interaction of political parties.

The state, regardless of political ideologies that rest on it, is certainly a major although complex actor. The state is now conceived not only as a set of three classic powers -government, parliament, courts- and thus with different levels of decision making, but also as a bundle of elites, institutions and political relations, without forgetting that it occupies a public space in which social, economic and cultural powers intersect and influence. Finally, the current State is increasingly characterized as an area of power that not only imposes behavioural patterns but also arbitrates between other powers solutions of a very varied spectrum, either inward, or associated with other States to face the problems of globalization.

\subsection{Curriculum}

Education policy has not yet paid much attention to the curriculum. While sociologists have addressed social aspects of the curriculum, political scientists have devoted little of their time to the complex relationship between politics and curriculum. And yet many of the essential changes have occurred since 1945 in developed countries, as a result of major economic, social and political transformations generated, they have attempted to deal with education from two main approaches: by changing the structure of education systems and reforming the curriculum.

The curriculum as an object of education policy covers, however, many large and important aspects. Without trying to be exhaustive, we could already list the following: the symbolic function of curriculum policies, the curriculum as a reflection of educational ideologies, the process of political decision making around the curriculum, the study of the mandate in the prescriptive curriculum, the centralized or decentralized framework of the curriculum, the success or failure of curriculum policies, etc.

The simple statement of the problem tells us that we know little of the relations between politics and the curriculum (Elmore and Sykes, 1992). We know little about the role of certain actors -individual and social- when considering the development of these policies, that is, the ability to influence or pressure from certain groups (the case of the Catholic Church is one of them; teacher unions are another).

We know little about the influence of curriculum policy effectively in the classroom and its relationship with studies on the school culture. We know little about the interplay of interests, whether legitimate or not. We know little about that relationship between state and curriculum, especially considering that relationship from the historical dynamics, that is, from the diachronic relationship between the classical liberal State or the social State of our days and the curriculum as well as the current neoliberal influences in curriculum policy.

\subsection{Educational policies}

Studies on public policies have been wise to focus on the specific problems of post-industrial societies, providing knowledge and making practical options easier for decisionmaking political actors. But as the decade of the eighties of the last century saw the growth of very good studies on social policies (health, planning, housing) there were few, very few people that addressed educational policies from the perspective of public policy, perhaps because, for various reasons, education has not been taken into account when studying the different aspects of social welfare.

Also because in the relationship between politics and education the stigma of past partisan distortions is still present, which explains, without a doubt, that the contributions are still scant, fragmentary, and sometimes of a dubious nature.

But this should not be an obstacle to recognize that the contributions derived from the public policies approach, some of them empirically recognized, open a highly suggestive path for the consideration of educational policy as a policy of education, not unconnected to the more general politics framework. However, it is necessary for the school of public policy to face two of the major criticisms trends that are made from these studies: its strongly ahistorical character and the absence of a theory to back them up, which is just the consequence of an understanding that gives priority to the efficiency of public policies.

It is obvious that our discipline has little to say about the lack of a sufficiently general theory that supports the movement of public policies, but it cannot but feel challenged when it comes to the need to apply the historical method to educational policies. Today we know that many of the current conflicts that education policy should study, and that educational policies are trying to solve, are loaded with historicity. The action of the State in education, and the resistance it continues to find in certain social groups only has a proper understanding from a historical perspective.

What is significant today is that this phenomenon, full of historicity, is not just confined to education. The story has come to occupy an important role in all political science studies because the political reality is part of a dynamic structure in which political events are mixed with other social facts, and therefore, as such, subject to historical change.

\section{CONCLUSION}

Not even two decades ago political scientists have started to take into account some questions that inevitably take us to history: traditions that have a weight on the current facts, conceptions that are results of a more or less distant past, institutions that are 
only explained according to their own historical genesis and evolution. We should rejoice in it and persevere in the historical study of the education policies, called to clarify certain aspects still in the shadow within the field of education, contributing to consider education from the perspective that is our own -as a political phenomenon of an extraordinary interest.

\section{REFERENCES}

Aristotle (2002). Nicomachean Ethics. Oxford: Oxford University Press. Bodin, J. (1985). Los seis libros de la República. Madrid: Tecnos. Duverger, M. (1981). Métodos de las ciencias sociales. Madrid: Ariel.

Elmore, R. \& Sykes, G. (1992). Curriculum policy. In Jackson, P. H. Handbook of Research on Curriculum. New York: MacMillan Publishing Company.

Machiavelli, N. (1997). The Prince. New York: Yale University Press. Montesquieu, C.L. (1985). Oeuvres Completes(2). Paris: Gallimard.

Mouffe, CH. (2007). En torno a lo político. Buenos Aires: Fondo de Cultura Económica.

Plato (2005). The Republic. Cambridge: Cambridge University Press.

Rousseau, J. J. (1971). Oeuvres Completes(3). Paris: Gallimard. 